\title{
HK2 wt Allele
}

National Cancer Institute

\section{Source}

National Cancer Institute. HK2 wt Allele. NCI Thesaurus. Code C51050.

Human HK2 wild-type allele is located within 2p13 and is approximately $61 \mathrm{~kb}$ in length.

This allele, which encodes hexokinase-2 protein, plays a role in the phosphorylation of glucose to produce glucose-6-phosphate. 